\title{
Preliminary report of an association between measles virus and achalasia
}

\author{
DAVID B JONES, JOHN F MAYBERRY, JOHN RHODES, JULIA MUNRO*
}

From the Department of Gastroenterology, University Hospital of Wales, Cardiff, and the *Public Health Laboratory Service, Cardiff

SUMMARY Complement fixation tests were performed on sera from 18 patients with achalasia and 12 age- and sex-matched controls against a number of bacterial and viral agents in an attempt to ascertain any association with previous infection or any evidence of an altered immune response. There was a statistically significant increase of antibody titre against measles virus in the sera of 21 patients with achalasia compared with age- and sex-matched controls and this was confirmed by haemagglutination inhibition.

Achalasia is an uncommon disease ${ }^{1}$ characterised by a disturbance in swallowing associated with denervation of the oesophagus and retention of food and saliva by the lower oesophageal sphincter. The findings of Cassella ${ }^{2}$ and Franzini and Pellegrino ${ }^{3}$ suggest that the primary lesion affects the dorsal motor nucleus of the vagus; this leads to Wallerian degeneration of the vagus producing atrophy of the smooth muscle of the oesophagus.

A similar South American condition known as Chagas' disease is characterised by denervation of the lower gut due to an altered immune response to Trypanosoma cruzi. ${ }^{4}$ We have looked for evidence of a bacterial or viral aetiology for achalasia.

\section{Material and methods}

Initially complement fixation tests ${ }^{5}$ against Trypanosoma cruzi were performed on sera from 15 patients with achalasia. Subsequently, complement fixation tests were carried out "blind" on the sera of 18 patients with achalasia and 12 matched controls for the following bacteria and viruses-Chlamydia psittaci, Coxiella burneti, measles virus, influenza A and B, parainfluenza, adenovirus, mumps, respiratory syncytial virus, rubella, varicella zoster, herpes simplex and cytomegalovirus.

The preliminary results suggested an association with measles virus and we therefore carried out haemagglutination inhibition tests ${ }^{6}$ on the sera of 21 patients with achalasia and 21 age- and sex-matched patients drawn from the Department of Orthopaed-

Accepted for publication 4 January 1983 ics, who had no gastrointestinal symptoms or history of recent infection. Measles haemagglutination inhibition tests were performed using Wellcome HA measles antigen and negative control antigen, with rhesus monkey red cells. The sera were preabsorbed with a $50 \%$ suspension of red cells. Measles antigen for complement fixation tests was supplied by the PHLS. This is a tissue culture preparation of Edmonston B strain in Vero cells. An uninfected tissue culture control was used to retest the sera after the initial findings. The tests were all performed "blind."

The sex ratio of patients was 12 women and 9 men with an age range of 22 to $83 \mathrm{yr}$ and a peak incidence over 40 yr of age. The results were analysed by Student's $t$ test based on log titres. Statistical significance was also calculated $(\mathrm{p})$.

\section{Results}

The complement fixation tests were negative for Trypanosoma cruzi and showed no difference between patients and controls for Chlamydia psittaci or Coxiella burneti. The only virus which gave results which were significantly different from controls was measles (Figure). Fourteen of 18 sera had a titre of $1 / 32$ or greater compared with four of 12 controls $(t=3.124 ; \mathrm{p}<0.005)$. The geometric mean of the complement fixation titres for the 18 cases of achalasia was $1 / 39$ which is threefold greater than the corresponding value of $1 / 13$ for controls.

A significant difference was also noted with the haemagglutination inhibition tests for measles. Fourteen of 21 sera had a titre of $1 / 32$ or greater compared with seven of 21 controls $(t=2 \cdot 1, \mathrm{p}<$ 
Number of positive results at each titre level in patients with achalasia and healthy controls

\begin{tabular}{|c|c|c|c|c|}
\hline \multirow{2}{*}{$\begin{array}{l}\text { Dilution } \\
\text { of sera }\end{array}$} & \multicolumn{2}{|c|}{ Complement fixation test } & \multicolumn{2}{|c|}{ Haemagglutination inhibition test } \\
\hline & Achalasia (18) & Controls (12) & Achalasia (21) & Controls (21) \\
\hline $\begin{array}{l}\leqslant 1 / 8 \\
1 / 16 \\
1 / 32 \\
1 / 64 \\
1 / 128\end{array}$ & $\begin{array}{l}1 \\
3 \\
7 \\
4 \\
3\end{array}$ & $\begin{array}{l}4 \\
4 \\
3 \\
1 \\
0\end{array}$ & $\begin{array}{l}4 \\
1 \\
9 \\
3 \\
4\end{array}$ & $\begin{array}{l}5 \\
9 \\
5 \\
2 \\
0\end{array}$ \\
\hline
\end{tabular}

$0 \cdot 05$; Figure). The geometric mean for these titres in the 21 patients with achalasia was $1 / 31$, which is double the $1 / 17$ in controls. There was no correlation between age or duration of symptoms and antibody levels. (Table)

\section{Discussion}

The results suggest an association between raised antibody levels to measles virus and achalasia. However, the results are preliminary and require confirmation by other authors. A screen of 13 different antigens may produce a false-positive association and confirmation of the results by the haemagluttination inhibition test on the same subjects does not completely answer this criticism. The significant difference between the patient and control groups is largely based on differences within one titration step (1/16 to $1 / 32$ ), although blind analysis limited the effect of subjective interpretation and "normal"

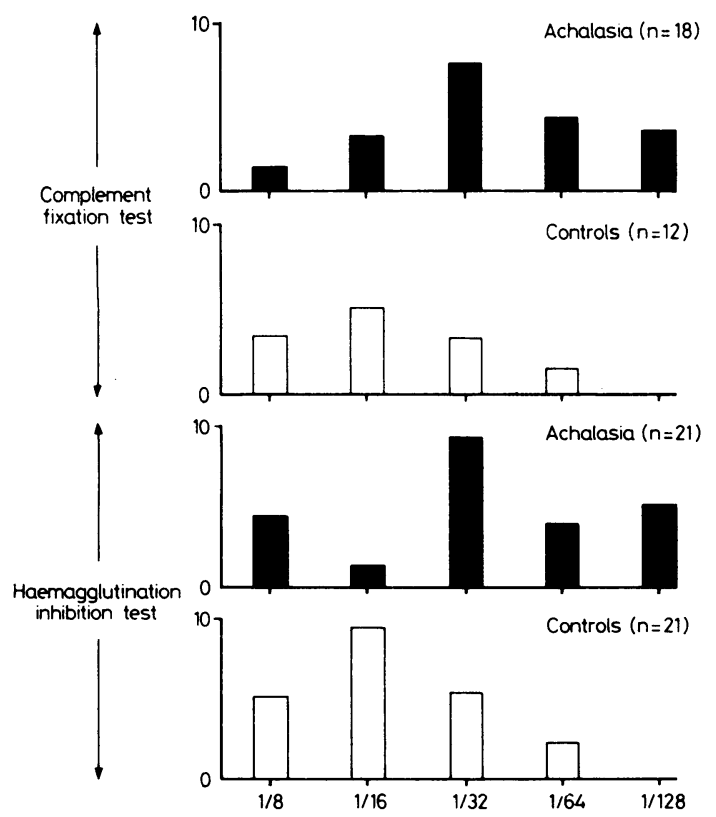

Antibody titres to measles virus in achalasia antigen was used in both the haemagluttination inhibition and complement fixation tests.

Necropsy studies of serial circumferential sections of the oesophagus have shown a markedly reduced number of ganglion cells, but normal smooth muscle. ${ }^{7}$ There is degeneration of vagal motor fibres and of the dorsal motor nucleus of the vagus. ${ }^{8}$ Any aetiological theory must explain the production of lesions in the ganglion cells and the more central vagal lesions, the tendency of the disease to occur in young individuals and a lack of clusters of cases. Another analogy exists between Chagas' disease and achalasia; the interval between acute infection with Chagas' disease and oesophageal, colonic and ureteric lesions may be many years. Perhaps in achalasia the oesophagus is exposed to a toxic substance or organism years before the disease becomes clinically manifest.

The significance of viruses in the development of oesophageal disease has recently been recognised following the work of Giger et al..$^{9}$ In a retrospective study of oesophagitis they demonstrated that in $1 \%$ of cases the origin was viral. In a prospective study of 119 cases of oesophagitis, herpes was isolated in 11 cases and also in five of 348 normal oesophaguses (Giger et al).$^{10}$ The oesophageal mucosa provides a suitable environment for viral replication. However, any association with measles virus is unlikely to be solely due to local effects and the precise role of measles virus is not clear. Measles virus has been implicated in the aetiology of several neurological diseases, including multiple sclerosis ${ }^{11}$ and subacute sclerosing panencephalitis. ${ }^{12}$ High titres may indicate an autoimmune cross reaction between antigenically similar components in measles virus and vagal nerve components. Certainly the levels of antibody titre do not correspond with those seen in panencephalitis.

To date there have been no convincing explanations as to the cause of achalasia. The rarity of the disease limits study, but the possible association between achalasia and measles virus warrants further investigation.

We wish to acknowledge the help of Dr DF Ridley of the Hospital of Tropical Diseases, London and 
Mr N Bishop of the Public Health Laboratory Services, Cardiff for help with the complement fixation tests and Dr R Newcombe of the Department of Medical Statistics, Welsh National School of Medicine, Cardiff for help in the analysis.

\section{References}

' Mayberry JF, Rhodes J. Achalasia in the City of Cardiff from 1926 to 1977. Digestion 1980;20:248-52.

${ }^{2}$ Cassella RR, Ellis FH, Brown AL. Diffuse spasm of the lower part of the oesophagus. Fine structure of oesophageal smooth muscle and nerve. JAMA 1965;191:379-82.

${ }^{3}$ Franzini C, Pellegrino C. Electron Microscopy (5th International Congress of Electron Microscopy, Philadelphia, Pennsylvania, Aug-Sept). New York: Academic Press, 1962:55-61.

4 Anonymous. Chagas' disease: potential for immunoprophylaxis. Lancet 1980;i:466.

s Bradstreet CMP, Taylor CED. Technique of complement fixation test applicable to the diagnosis of virus disease. Mon Bull Min Health and PHLS 1962:2196.
- Norby E, Gollmar Y. Appearance and persistence of antibodies against different virus components after regular measles infection. Infect Immun 1972;6:240-7.

' Cassella RR, Brown AL, Sayre GP, Ellis FH. Achalasia of the oesophagus: pathologic and etiologic considerations. Ann Surg 1964;160:474-87.

Smith B. The neurological lesion in achalasia of the cardia. Gut 1970;11:388-91.

- Giger M, et al. Diagnose und Häufigkeit der viralen Oesophagitis. Schweiz Med Wochenschr 1981;111:814-6.

${ }^{10}$ Giger M, Uehlinger M, Bansky G, Hacki W. Herpes virus and Candida in oesophagitis: a prospective study. Scand J Gastroenterol 1982;17:suppl 78:61.

"Adams JM, Imagawa DT. Measles antibodies in multiple sclerosis. Proc Soc Exp Biol Med 1962;111:562-6.

${ }^{12}$ Connolly JH, Allen IV, Hurwitz LJ, Millar JID. Measles virus antibody and antigen in subacute sclerosing panencephalitis. Lancet 1967; i:542-4.

Requests for reprints to: Dr J Rhodes, University Hospital of Wales, Heath Park, Cardiff CF4 4XW, Wales. 